\title{
GOPLUS GEOSPATIAL DATA SERVICE FOR INDUSTRIAL AND INFRASTRUCTURE DEVELOPMENT IN ODISHA, INDIA
}

\author{
Debajit Mishra $^{1, *}$, Manoj Kumar Sanabada ${ }^{1}$, Seshadev Sahu ${ }^{1}$, Srikant Das ${ }^{1}$, Sandeep Tripathi ${ }^{12}$ \\ ${ }^{1}$ Odisha Space Applications Centre, Odisha, India - djmishra@yahoo.com \\ ${ }^{2}$ Odisha Forest Department, India
}

Commission V, WG V/4

KEYWORDS: GOPLUS, Land Bank, Ortho image, Web-GIS, Geospatial data, Geocoded data, RoR (Record of Rights)

\begin{abstract}
Technological advancement is the key driver for economic growth and sustainable development. Geospatial Technologies applications and tools available today are being used for improved performance of a country towards all major verticals of economy. In a bid to attract investment and ensure hassle-free land acquisition for major projects, the Odisha government decided to create land banks for industrial development using advanced technology applications. In the present paper Geo-informatics, ICT and space technology inputs are used to create Web-GIS based solutions for Land Bank creation. High resolution ortho-images, geo-referenced digital revenue cadastral datasets, Revenue RoR data, satellite derived spatial datasets and utility attribute datasets of state department are used to create the Web-GIS Odisha land bank. Emphasis was given to develop a portal that offers an interactive platform and provide detailed information with regards to availability of industrial plots or land plot clusters based on location specific attributes in terms of connectivity, rail and road linkages and other physical and social infrastructure available in the vicinity. Conversely, the developed system helps an investor to identify suitable land plots in the vicinity of the utility, sub-utility selected by an investor as per his requirement. It enables prospective investors to identify suitable land in Odisha from the comfort of their offices. A prospective investor can define preferred parameters such as the district, size of land required, facilities available in the vicinity and proximity to existing developed infrastructure etc. based on which the portal identifies and returns information regarding the suitable land parcels available in the State. The outputs are web-hosted in public domain for use by all stakeholders interactively under GOPLUS (Govt. Odisha Portal for Land use and Services) through gis.investodisha.org.
\end{abstract}

\subsection{INTRODUCTION}

Land is one of the most important factors in economic development today and must be managed well to enhance socioeconomic conditions of communities. Government departments, industrialists and business communities are facing difficulties to implement their development plans because of shortage of appropriate lands. Therefore, technological solutions are searched for creation of land banks. Land banks are large area of land held by Government, public or private occupancy for future development or disposal. Land Banking is the strategic acquisition of land in advance of expanding urban and industrial development; the practice of buying and holding underdeveloped and pre-developed land for productive and future use (Hartvigsen, 2015). In the present paper geoinformatics, ICT and space technology inputs used to create the Web-GIS based Odisha Land Bank for industrial development.

The study emphasis in this paper is applications of Geo-ICT, GIS, Space applications and web-technology to provide centralized database service to decision makers, administrators, investors, planners and common public for industrial and infrastructure development. The efficacy of digital database for providing information to investors along with options of data supply about developed facilities, services, utilities, infrastructure and amenities around the identified land clusters are other aspects of portal design attempted in this study. Provision of information along with spatial and attribute data to potential investors for new ventures and dissemination of industrial information in public domain in a spatial format for the access and appreciation of common citizen are also embedded to the model developed. Spatial relationship between

* Corresponding author industrial clusters, infrastructure and other amenities through an overlay of attributes that measures the suitability of industrial development are established. As per the need of investors the portal design tried to create inventory and prioritise land utilization to provide strategic direction to industrial and economic development in Odisha state (Invest Odisha Team, 2015 \& 2016). The portal developed under this study i.e. GOPLUS (Govt. of Odisha's Portal for Land use and Services) (GOPLUS development team, 2016) is a GIS based industrial land use and infrastructure information system. GOPLUS is a web enabled platform to display real time information with regards to land bank, utilities and infrastructure around land banks besides information about existing industries.

\subsection{Study Objectives}

- Technology application (Geo-ICT, GIS, Space applications and web-technology) to provide Land Bank related centralized database service (Acharya, 2009).

- Creating digital database of "Land Bank" for investor's information along with options of data supply about developed facilities, services, utilities, infrastructure and amenities around the identified land clusters.

- Solutions for providing spatial and attribute data to potential investors for new ventures.

- To develop and design data provision service (Industry location with info, about estates, sector specific clusters, industrial parks, special economic zones and industrial parks etc.) in public domain in a suitable format for the access and appreciation of common citizen and other stakeholders. 


\section{METHODOLOGY}

In order to prepare land banks the revenue cadastral maps are digitised and geo-referenced with Ortho-images generated by using stereo pair data of Cartosat satellite and available DGPS based GCP datasets collected covering 314 administrative blocks of the state. The revenue Record of Right (RoR) data available in SQL data format are linked to corresponding plots. Along with this the state administrative maps depicting village, grampanchayat, block, district boundaries etc. major road and rivers is also georefereced with the state level ortho mosaic developed for the state under ISRO, Dept. of Space SIS-DP project (Fig.1).

\subsection{Development of Land Bank maps and data}

Revenue cadastral maps are used as base maps for creating spatial database. Initially the plots are listed considering its government ownership. The listed plots are identified on cadastral maps. The shape files of cadastral maps linked with RoR data are used for identification of plots. Clustering was made considering its shape, size, landuse, location, physiography, morphology, connectivity and contiguous nature. Ortho-rectified Cartosat $2.5 \mathrm{~m}$ and World-View $0.5 \mathrm{~m}$ data are used to geo-reference the plot clusters. Land Bank cluster maps are prepared in revenue scale in digital dwg and shp format. Along with the new land bank maps the database of 106 industrial Estates, industry location maps and database of 11 sector specific cluster development maps are created using industry department maps. All these maps are converted to one common base map format as mentioned above in section 2.0.

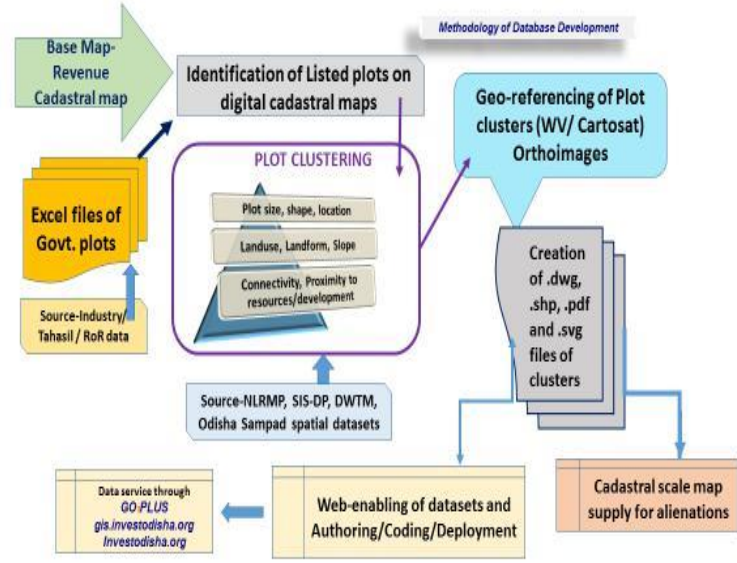

Figure 1. Methodology of Land Bank Preparation

\section{Outputs generated:}

- $\quad$ Land Bank clusters identified and mapped for 2.4 lakh hectares in 22 districts of the state.

- $\quad$ Land Bank map, data and land schedule for 1.14 lakh Acres are made available in cluster format for public use.

- GIS database of 106 industrial Estates, industry location maps and database of 11 sector specific cluster development are made using industry department maps.

\subsection{Development of thematic and Utility maps and Geo-coded data}

In order to provide detailed information with regards to availability of industrial plots or land plot clusters based on location specific attributes in terms of connectivity, rail and road linkages and other physical and social infrastructure available in the vicinity; point source data on bank, ATM, school, colleges, technical institutes, hotels, power stations, police stations, fire stations, public health centres, district hospitals, mines and industry location maps are collected by GPS and GIS database is created and linked to state level base map. Thematic maps relating to rivers, water body (Dam, WHS, Tank and Pond etc.) road and rail network, settlement spread, forest patches are prepared by onscreen digitisation of georeferenced Cartosat and World view data. Thematic maps are also prepared using secondary map database of state level space applications centre.

\subsection{Database developed for portal development using Remote Sensing and GIS}

\begin{tabular}{|c|c|}
\hline Component & $\begin{array}{ll}\text { Attributes } \quad \text { required } & \text { for } \\
\text { selecting sites for industry } & \end{array}$ \\
\hline \multirow[t]{3}{*}{$\begin{array}{l}\text { Land Bank } \\
\text { Clusters }\end{array}$} & $\begin{array}{l}\text { Geo-coded cadastral level plot } \\
\text { boundaries, }\end{array}$ \\
\hline & $\begin{array}{l}\text { Size of land parcels land bank } \\
\text { clusters }\end{array}$ \\
\hline & $\begin{array}{l}\text { Infrastructure/ amenities/ } \\
\text { services around Land Bank }\end{array}$ \\
\hline \multirow[t]{3}{*}{ Infrastructure } & Surface water \\
\hline & $\begin{array}{l}\text { Power supply- Transmission \& } \\
\text { distribution }\end{array}$ \\
\hline & Electric substations \\
\hline Transportation & $\begin{array}{l}\text { Transport Corridors - National \& } \\
\text { State Highways/ Other major } \\
\text { roads, Rail Networks/ Railway } \\
\text { stations, Port connectivity }\end{array}$ \\
\hline \multirow[t]{2}{*}{$\begin{array}{l}\text { Social } \\
\text { Infrastructure }\end{array}$} & $\begin{array}{l}\text { 8. Schools, Colleges, Hotels, } \\
\text { Medicals facilities, Bank/ATM }\end{array}$ \\
\hline & $\begin{array}{l}\text { 9. Technical Institutions, } \\
\text { Police stations, Fire stations }\end{array}$ \\
\hline \multirow[t]{2}{*}{ Environmental } & 10. Rivers/ Waterbody \\
\hline & 11. Forests (RF/PF) habitations \\
\hline $\begin{array}{l}\text { Administrative } \\
\text { zones }\end{array}$ & $\begin{array}{l}\text { 12.Settlement locations/ village/ } \\
\text { Gram Panchayat/ Tahsil/ Block/ } \\
\text { District }\end{array}$ \\
\hline
\end{tabular}

Table 1. List of Database developed for the project

\subsection{GIS Database generated}

The major aspects of the study is developing standardized accurate geo-referenced/geo-coded database of all 314 blocks (30 districts) of the state.

Generation of ortho-images of the state by the help of Cartosat stereo pair data and DGPS based ground observation (Ground Control Points in $4 \mathrm{~km} \mathrm{x} 4 \mathrm{~km}$ grid) and demarcation of utilities, infrastructure on the images. 
Digitisation/coding/geo-referencing of 2.5 lakh villages maps sheets (showing revenue/ cadastral plot boundary) with Cartosat and Worldview ortho-images.

Preparation of utility/maps of the entire state (GPS based Geo-coordinate collection). The utilities are Power stations, Schools, technical institutes, hospitals, higher education centres, banks, ATM, police station, fire station, hotels(major) and Industry office coordinates of the entire state.

Preparation of thematic maps from latest satellite images like river/water bodies, drainage, settlement location, tree cover in industrial estates, ground water prospects, mines and mineral location and road network (up to village road) of the entire state.

Preparation of network maps of Odisha state $(\mathrm{NH}, \mathrm{SH}$, ODR, MDR, Railway line, Rail station, Power substation, Power line, Canal, Airport/Airstrip, Seaport, Helipad etc.)

Preparation of georeferenced maps of all 106 industrial estates, location of all major industries inside and outside the industrial estates, land bank clusters, IPICOL DIC industries, sector specific parks/regions, land cost, industry pollution category, tree inside estate and industry related offices (DIC office, Labour office, Factories and Boilers, ESI, IDCO/IPICOL offices).

Most important aspect is Integrating Multi source, Multiscale and Multi-format datasets into one common format for display and interactive queries (Table 1).

For the first time in the state a digital, structured database of Industrial estates of the state is created.

\section{0}

\section{DEVELOPMENT OF WEB-PORTAL}

The objective of the study is to generate a portal to provide detailed information pertaining to land with regards to availability of industries, plots under land bank cluster and location specific attributes in terms of connectivity, linkages and availability of other utilities, amenities and services. Significantly under this application query based spatial and attribute search and information extraction is provided in webportal in public domain for benefits of all types of stakeholders. The sequence of activities adopted to generate the web-portal is described below.

\subsection{Installation of the software}

Sequence of the software installation is:

a) Oracle Database 32/64 bit Software

b) Oracle Database client: If 64 bit software is installed

c) Oracle SQL Developer configured and tested for Oracle database connection

d) Visual studio 2012 installed.

e) Oracle ODAC software installed to make the ODBC connection from Application to database.

f) ArcGIS Desktop: License configured properly.

g) Compatible version of IIS Manager loaded.

h) ArcGIS Server: ArcGIS Server Post installation is done to work well with IIS Manager.

\subsection{Development Procedures}

I) Map Authoring: Maps used in website are given below (The database created and listed in section 2.3 above.

- Industry Locations, Industrial Estates, Land Banks, Plots and Important official setups are included in Industry Info Map Document (.mxd).
- Administrative boundaries like State, District, Block, Village, Gram Panchayat and Habitations are represented in Administrative Map document (.mxd)

- $\quad$ National Highway, District Roads, Other Roads, Railway Stations, Railway Lines, Power Sub stations, Power Lines, Canal, Bank and Airport \& Ports are in Network Infra map Document.

- Physical/Natural Resources map contain River/Waterbody, Drainage, Forest and Habitation Layers.

- Social Infra Map Document contains Health, Police stations, Fire stations, Technical Institutes, Hotel, Schools, Colleges information as layer.

II) Map Publishing:

- $\quad$ Maps Prepared in previous steps are published to ArcGIS server, So that authored maps can be accessed via URL.

III) Oracle Database Preparedness:

- Industrial Data in Excel format are entered to Oracle Database via Oracle SQ1 Developer software using Import tool.

IV) Coding:

- Visual studio is used for development of website to support client/server communication to fetch the Oracle database and showing it to web.

- $\quad$ HTML 5 is used for the Interface of website.

- Dojo Libraries are used for GIS Functionality/Tools of the website.

- This site is developed on widget Programming pattern, which provides Object-oriented programming approach in website development.

- $\quad$ All the tools are developed separately from its interface design and finally bound together to work as a unit.

- Website is programmed in such a way that widget codes are hidden from the user.

V) Deployment:

- $\quad$ Public IP (164.100.141.84) assigned to the Development server to access all the published map services on ArcGIS Server. As map services are accessed via URL, so the same public IP is used in URL in the code to make it accessible globally.

- Gis.investodisha.org is the URL to access the website, so one directory with the same name has been created in Local IIS Manager of the development server.

- Domain name (gis.investodisha.org) (GOPLUS-Govt. of Odisha Portal for Land Use Services) is given to the development server, so if user hits the gis.investodisha.org, it redirects the request to the public IP. The landing page created is shown in Fig.2.

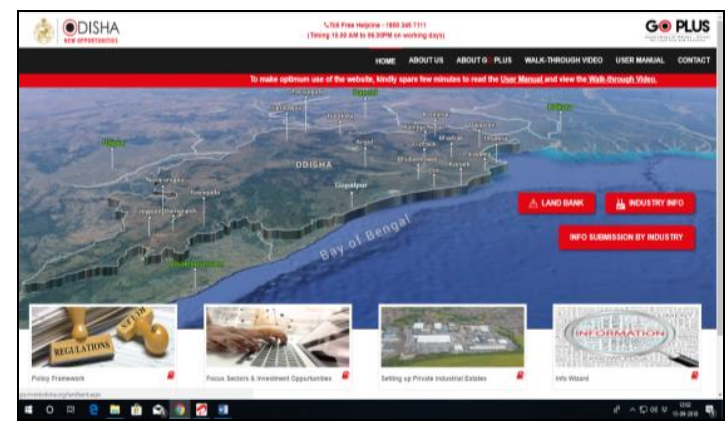

Figure 2. Landing Page design of the web-portal

\subsection{GOPLUS Service facilities created}

GOPLUS is a web enabled platform to provide investor friendly services and provides information on Land Bank of Odisha. It maps the existing land parcels and its status along with a query analysis that provide a glimpse of developed infrastructure. 
Database of industrial land use and infrastructure along with social infrastructure facilities.

- Provides a spatial relationship between industrial clusters and infrastructure and other amenities through an overlay of attributes that measures the suitability of industrial development.

- Creating inventory and prioritise industrial land utilization to provide strategic direction to industrial and economic development.

\section{QUERY MODULES CREATED FOR USER}

For the benefit of users to obtain landbank information the following modules are created.

- Land bank at a glance

- Search by location and

- Land bank search around utilities

The flowchart below depicts the details of the three user query modules developed in GOPLUS portal (Fig.3).

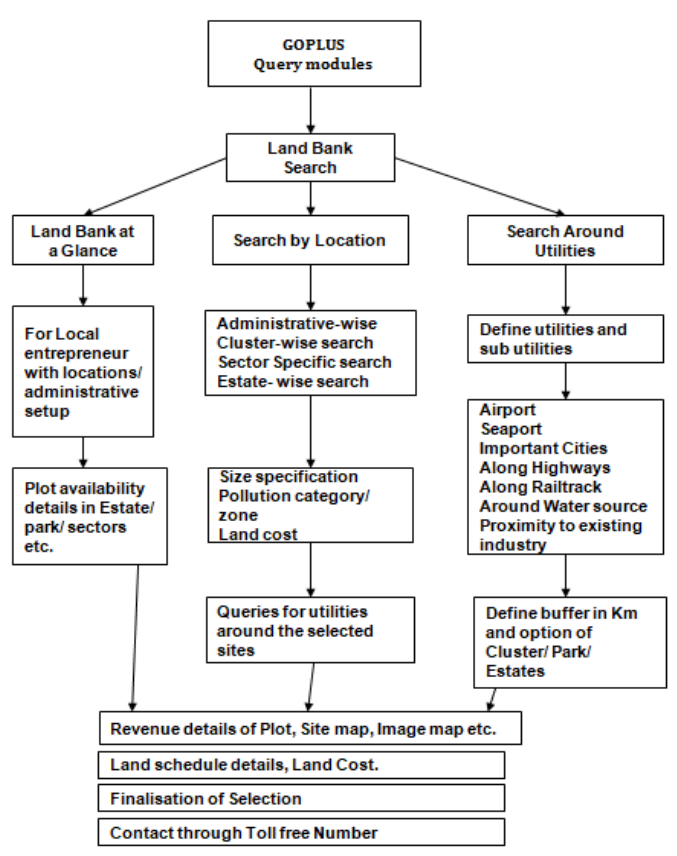

Figure 3. User Query Modules in GOPLUS

\subsection{Land Bank map/data services}

Option is created in simple query module to select plot clusters available in 30 districts and 314 blocks of the state for state and country level investors. The user can find out a land plot of choice in the State under the 'Land Bank' tab based on the size of land required (Fig 4 and 5).

For 5 acres and less - The user can click on 'Land Availability in Parks/Estates'. To find a piece of land inside investment region/industrial clusters and Industrial Estate, the user can select 'Vacant Search in Region' and 'Vacant search in Estate' respectively. Under that, the user can enter the size range and get all the available land plots matching the users' criteria. The user can further refine the search by selecting the Investment Region/Industrial Cluster/Industrial Estate of choice and get detailed information about the selected land plot

For more than 5 acres - In case the user is aware of the district, category and cluster, the user can directly select those from the drop down list and find out available land plots. Or else the user can click on 'Cluster/Patch Search' and select 'Search by Area'. Under search by area, the user can enter the size range and get all the available land banks in the State matching the criteria. Further the user can refine the search by selecting the district.

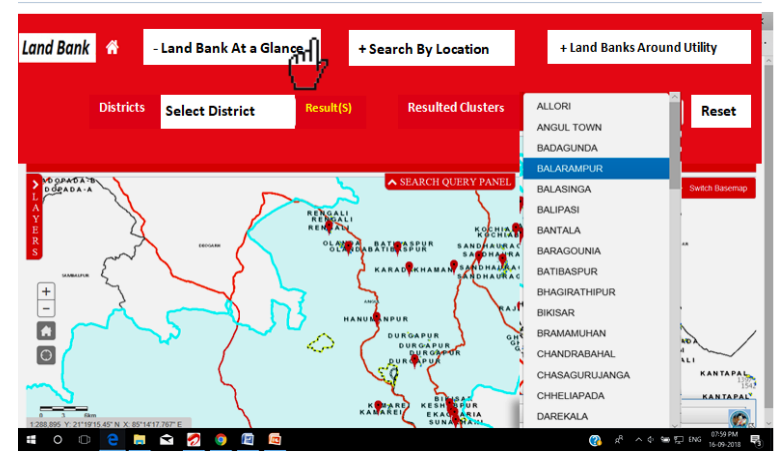

Figure 4. Land Bank at a glance module to obtain land available in administrative zones i.e. districts or blocks

\subsection{Land Bank map/data services}

The portal has interactive options to get all details of a selective cluster such as revenue record of rights, size, ownership, cost and permissible industries under defined pollution category. Map and data sheets (in .pdf and. excel format) get displayed with the display results as shown in Fig 5.

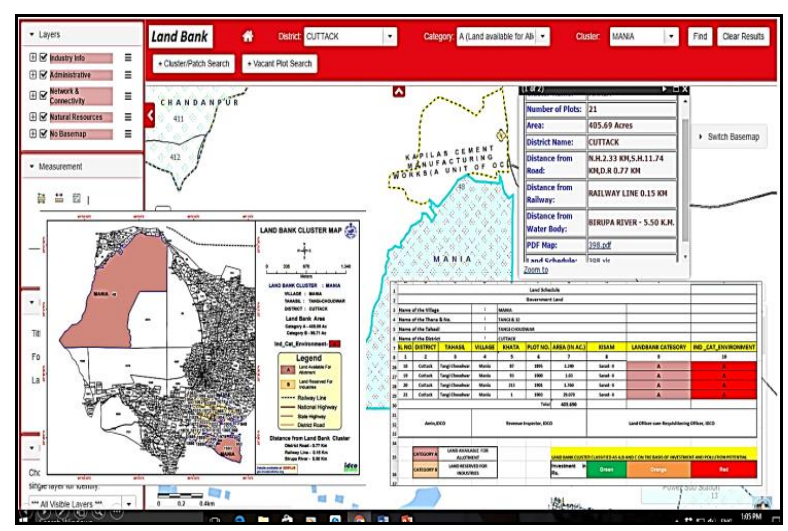

Figure 5. Land Bank Search Module to provide plot details, cost, pollution category etc.

The Query button named "Utilities around Land Bank" contains options of queries such as selection of utilities \& size range details. User can search the Utilities based on the selection of facilities in the specified buffer area in $\mathrm{km}$.

\subsection{Utilities around selected land bank cluster}

Users can obtain information (Geo-locations) about available utilities and developed infrastructure around a land cluster once identified or selected. The Fig 6 depicts the query module developed for the purpose. User can get info about distance of national or state highway, rail facility, airport, seaport, water source, power stations, banks, health and education centres, hotels and police stations etc. 

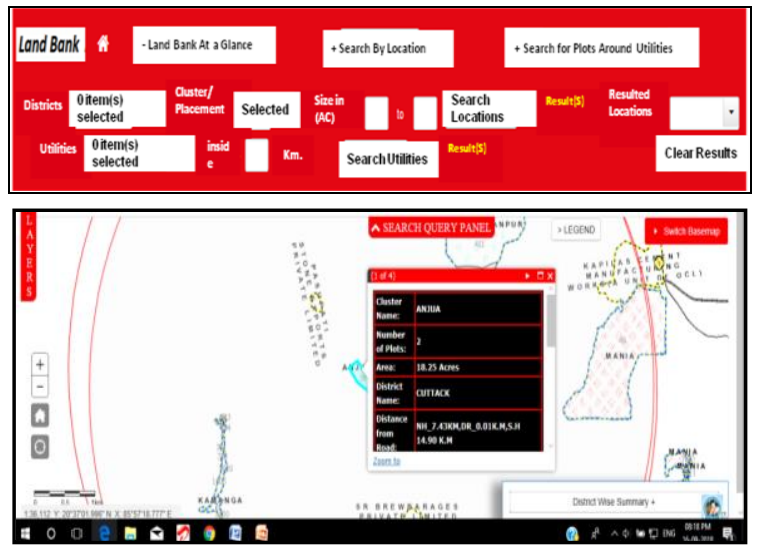

Figure 6. Land Bank Search Module to provide utilities location around a selected sites with buffer in $\mathrm{Km}$.

\subsection{Land Bank around Utilities}

The Query button named "Land bank around Utility" contains options to find the land banks based on the utility, sub-utility provided within specified area. Results get displayed on the map section as shown in Fig 7. Investors interested to establish industries around airport, seaport, rail corridor, special economic zones, and industrial parks can select these locations and find land available for locating new industries.

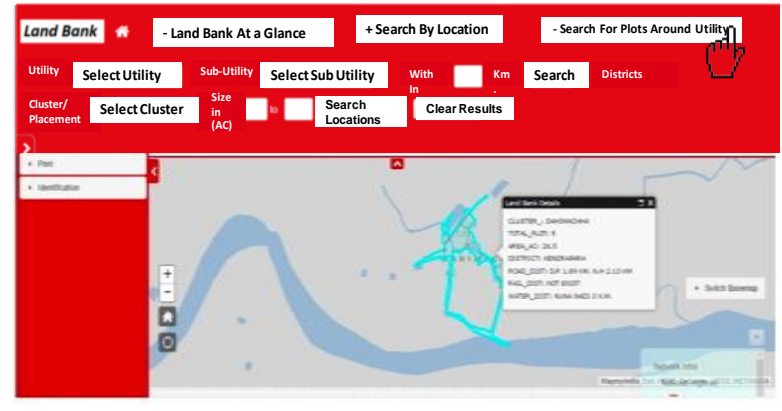

Figure 7. Land Bank Search Module to provide plots around selected utilities

Land Availability in Parks/Estates: This search gives options to find plots of area less than 5 Acres. One can search vacant plots by in Sector Specific clusters, Investment regions and Industrial estates on the basis of the areas required by the user. It also helps the user to search a particular Sector Specific clusters or Investment regions from the list available.

The Query button named "Vacant Search in Region" contains options to search the information of vacant plots in Sector Specific clusters and Investment regions by providing the range of Parcel Area (in Acres). Click on Get Parcels Map gets displayed with the display results of vacant plot details as shown in Fig 8. The Query button named "Search the Region/Park" contains options to select the Sector Specific Clusters and Investment regions from the drop down list.

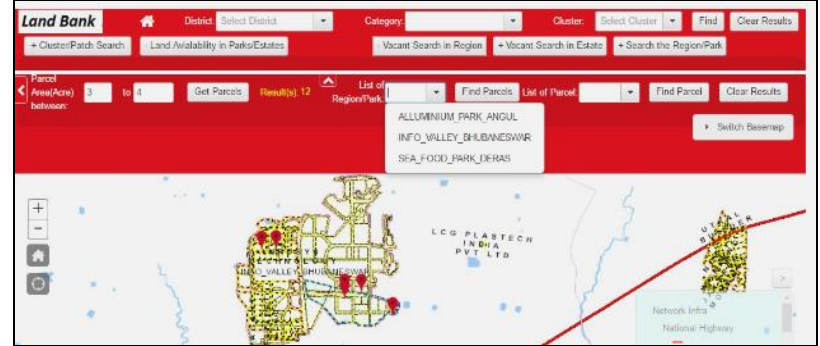

Figure 8. "Vacant Search in Estates/Region" contains options to Search Vacant Plots

\section{0}

\section{CONCLUSION}

The portal is an interactive platform and provides detailed information with regards to availability of industrial plots based on location specific attributes in terms of connectivity, rail and road linkages and other physical and social infrastructure available in the vicinity of the selected industrial land Conversely, the system helps an investor to identify suitable land plots in the vicinity of the utility, sub-utility selected. It enables prospective investors to identify suitable industrial land in Odisha from the comfort of their offices. A prospective investor can define preferred parameters such as the district, size of land required, facilities available in the vicinity, etc. based on which the portal identifies and returns information regarding the suitable the land parcels available in the State. It also provides information on zoning of the industrial land in terms of environmental categories i.e. Green, Orange and Red to enable an investor decide on suitable location for the proposed business activities. Using another feature of the portal a prospective investor can get detailed information about the key attributes of existing industries operational in a particular cluster. This information connects buyers and sellers of a particular product and helps establish backward and forward linkages.

The system is of great use to the state officials and is being regularly used by them. The various decision makers that are extensively using the portal are a) IDCO (Odisha Industrial Infrastructure Development Corporation, the nodal agency of providing industrial infrastructure in Odisha); b) IPICOL (industrial Promotion \& Investment Corporation of Odisha Limited, the State Level Nodal Agency and Investment Promotion Agency for the Industries Department, Government of Odisha.); c) Regional / District Industries Centres, the District Level Nodal Agencies for industrial promotion and investment corporation, catering to Micro, Small and Medium Enterprises; d) Prospective Investors. Geospatial technology based decision support systems provides inputs for smart growth strategies and policy framework. Digital web-based datasets provide critical information in the decision making process and planning for future industrial developments in the state

\section{ACKNOWLEDGEMENTS}

The authors are thankful to the project assistants of GOPLUS project team, officials of Industries department of Govt. of Odisha and Facility Iincharges of Odisha Space Applications Center (ORSAC, Dept. of Science and Technology, Govt. of Odisha) for their help in preparing the paper. 


\section{REFERENCES}

Hartvigsen, M., 2015. Experiences with land Consolidation and land banking in central and Eastern Europe after 1989", Working paper no-26, FAO, United Nations, Rome.

Invest Odisha Team, Government of Odisha, 2015, Industrial Policy Resolution, Govt. of Odisha publication, Bhubaneswar, Odisha. https://investodisha.gov.in

Invest Odisha Team, Government of Odisha, 2016, Ease of Doing Business in Odisha, Dept. of Industries, Govt. of Odisha publication, Bhubaneswar, Odisha. https:// investodisha.gov.in/

GOPLUS Development Team, version.1.0, 2016, http://gis. investodisha.org/

Acharya, Babu Ram, 2009, Adopting geo-ICT for land administration: problems and solutions. $7^{\text {th }}$ FIG Regional Conference. Retrieved from www.fig.net/pub/Vietnam /papers/ ts01e/ts01e_acharya_3656.pdf. 